\title{
Gene therapy for mucopolysaccharidosis
}

\author{
Katherine P Ponder ${ }^{1, \dagger}$ and Mark E Haskins ${ }^{2}$ \\ ${ }^{1}$ Washington University School of Medicine, Departments of Internal Medicine and Biochemistry \\ and Molecular Biophysics, 660 South Euclid Avenue, St. Louis, MO 63110, USA, Tel: +1 314362 \\ 5188; Fax: +1 314362 8813; kponder@im.wustl.edu \\ ${ }^{2}$ University of Pennsylvania, Department of Pathobiology, School of Veterinary Medicine, 3800 \\ Spruce Street, Philadelphia, PA 19104, USA
}

\begin{abstract}
Mucopolysaccharidoses (MPS) are due to deficiencies in activities of lysosomal enzymes that degrade glycosaminoglycans. Some attempts at gene therapy for MPS in animal models have involved intravenous injection of vectors derived from an adeno-associated virus (AAV), adenovirus, retrovirus or a plasmid, which primarily results in expression in liver and secretion of the relevant enzyme into blood. Most vectors can correct disease in liver and spleen, although correction in other organs including the brain requires high enzyme activity in the blood. Alternative approaches are to transduce hematopoietic stem cells, or to inject a vector locally into difficult-to-reach sites such as the brain. Gene therapy holds great promise for providing a longlasting therapeutic effect for MPS if safety issues can be resolved.
\end{abstract}

\section{Keywords}

gene therapy; glycosaminoglycan; lysosomal storage disease; mucopolysaccharidosis

\section{Introduction}

The mucopolysaccharidosis (MPS) syndromes [1] are lysosomal storage diseases with an overall incidence of 1:25,000 [2] that involve deficient activity of enzymes which degrade glycosaminoglycans (GAGs). Table 1 summarizes the MPS syndromes, the enzymes that are deficient, the GAGs that they metabolize, and some of the major organs that are affected. All are autosomal recessive diseases except for the X-linked MPS II, and most of the syndromes have a variable phenotype from mild to severe, which correlates reasonably well with the level of enzyme activity. GAGs are complicated polymers of sulfated and $\mathrm{N}$ acetylated sugars that are added to proteins post-translationally and serve a variety of important biologic functions. Organs vary in the amounts of different GAGs that they produce, which results in differences in the clinical manifestations for each syndrome. For example, heparan sulfate (HS) is very abundant in the brain, and neurologic disease develops in the disorders with deficient activity of enzymes that are important for HS degradation (MPS I, MPS II, MPS III and MPS VII). Conversely, as chondroitin sulfate (CS) is abundant in cartilage, bone and joint disease are most severe in the disorders with deficient activity of enzymes that are critical for CS catabolism (MPS IV, VI and VII). In some sites, such as heart valves, the physical accumulation of GAGs results in thickening of

\footnotetext{
(C) 2007 Informa UK Ltd

${ }^{\dagger}$ Author for correspondence.
} 
the organ, which causes dysfunction. However, in many organs such as the brain, it is unclear as to how GAG accumulation results in clinical symptoms.

Existing therapies for MPS include enzyme replacement therapy (ERT) [31] and hematopoietic stem cell transplantation (HSCT) [4]. Both approaches rely on the unique pathway by which these enzymes reach the lysosome. Most soluble lysosomal enzymes acquire a mannose 6-phosphate (M6P) moiety during processing in the Golgi. M6Pmodified proteins bind to the M6P receptor (M6PR), which transports most of the enzyme produced by a cell to its lysosomes. However, a small fraction $(\sim 10 \%)$ of the enzyme is secreted despite the fact that it contains M6P. The secreted enzyme can be taken up by adjacent or distant cells in a process referred to as cross-correction, as the M6PR also appears on the surface of many cells. ERT involves intravenous (i.v.) injection of M6Pmodified enzyme, whereas HSCT results in migration of cells into organs where they secrete enzymes locally, as well as secretion of some enzyme into blood. ERT is now available for MPS I [5], MPS II [6] and MPS VI [7], but involves frequent i.v. infusions. In addition, it is very expensive at \$300,000-1,200,000 a year for adults based on prices at the authors' hospital. HSCT is effective for some disorders but has a $15 \%$ risk of early death, requires a compatible donor, and is moderately expensive at $\sim \$ 130,000$ per transplant [8-11].

\section{Post-translational modifications necessary for activity}

Some lysosomal enzymes require post-translational modifications that are essential for their catalytic activity. All sulfatases are modified post-translationally in the endoplasmic reticulum by sulfatase-modifying factor 1 (SUMF1) or SUMF2 [12]. These convert a cysteine to the $c$ - $a$-formylglycine that is required for catalytic activity for the enzymes that are involved in MPS II, MPS IIIA, MPS IIID, MPS IVA and MPS VI. This modification appears to be limited in muscle [13], although liver can efficiently perform this step and secrete sufficient amounts of active enzyme to exert a therapeutic effect for MPS II [14].

\section{Recent progress in gene therapy}

The most common form of gene therapy is when a gene that encodes a functional protein is transferred into an animal, resulting in long-term expression of the protein that was deficient [15-17]. In vivo gene therapy can involve systemic injection of vector into a peripheral vein, an artery or the portal vein, or localized injection into a specific organ such as the brain or muscle. Ex vivo gene therapy refers to removal of cells such as hematopoietic stem cells, modification in vitro, and infusion of the modified cells back into the animal or patient. Most viral vectors are derived from adenoviruses, adeno-associated viruses (AAV), retroviruses or herpes simplex virus (HSV) and involve replacement of some or all of the genes that encode viral proteins with the therapeutic gene. Adenoviral vectors have a linear $\sim 35 \mathrm{~kb}$ double-stranded genome, and can be maintained episomally for prolonged periods of time in non-replicating cells. AAV vectors have a linear single-stranded DNA genome of $\sim 4.7 \mathrm{~kb}$, which is converted to double-stranded DNA that concatemerizes and can be maintained episomally long-term in non-replicating cells, but occasionally integrates into the chromosome. Retroviral vectors have a 5-10 kb RNA genome that is copied to DNA and integrates into the chromosome, which is maintained stably even when cells undergo many rounds of replication, but can result in insertional mutagenesis as is discussed in more detail below. Finally, HSV vectors have a $150 \mathrm{~kb}$ linear double-stranded DNA genome, and can be maintained episomally in non-dividing cells.

Viral vectors are produced with packaging systems that express the viral proteins in trans. The choice of different capsid (adenovirus and AAV) or envelope (retrovirus) proteins can influence the binding to the cell surface and transduction of different cell types. Lentiviral vectors are a subset of retroviral vectors that can transduce both dividing and non-dividing 
cells, whereas $\gamma$-retroviral vectors are primarily derived from the Moloney murine leukemia virus and can only transduce dividing cells. The requirement for replication has potential safety advantages with in vivo administration, as it should preclude germline transmission if germ cells are not replicating, and might reduce the total number of cells that are transduced. However, in some cases, such as transfer to hepatocytes of adults, a stimulus needs to be given to induce cell division. Proteins can also be expressed from plasmids, which can direct long-term expression in the liver if they are deleted of bacterial sequences [18] or contain transposable elements that result in integration [19].

\section{Systemic gene therapy in mice}

Systemic gene therapy has resulted in continuous secretion of enzyme into the blood [20], and correction of disease in a fashion analogous to ERT. High levels of these enzymes in blood are unlikely to result in inappropriate degradation of GAGs that are serving important biologic functions in the extracellular space, as these enzymes only act on terminal sugars on GAG chains and function best at a low $\mathrm{pH}$. Although serum enzyme activity can reach very high levels, delivery to some organs is limited by diffusion barriers. Therefore, it is important to define the serum activity needed to result in functional and/or pathologic improvements in organs, which varies with the specific MPS syndrome, the vector, the age at administration, and the species. The target intracellular level is probably $>5 \%$ of normal enzyme activity, as heterozygous patients are normal, and those with low levels of enzyme activity usually have less severe symptoms than patients with no enzyme activity.

\subsection{Systemic gene therapy in newborn mice}

$A$ variety of AAV, adenovirus, $\gamma$-retroviral vectors, lentiviral and plasmid vectors have been injected i.v. into newborn mice with different MPS syndromes. As disease in liver and spleen can be corrected with very low levels of enzyme activity, the summary in Table 2 focuses on the effect in sites that are more refractory to treatment. MPS VII mice that achieved > 150-fold normal serum $\beta$-glucuronidase (GUSB) activity after neonatal retroviral vector-mediated gene therapy had a profound improvement in difficult-to-treat sites such as eye, aorta, and brain but those with < 150 -fold normal serum GUSB activity had only partial improvements [21]. For MPS I, achieving 250- to 500-fold normal a-L-iduronidase (IDUA) activity after neonatal retroviral vector gene therapy had a profound effect on all manifestations in mice, whereas 15 -fold normal activity was only partially effective in brain, eye, ear and bone, and was not effective in aorta [22,23].

Neonatal administration of AAV vectors resulted in very high initial serum expression, which fell to $\sim 5 \%$ of the peak serum activity in adults due to a reduction in the DNA copies in the liver as hepatocytes divided [24]. Achieving high serum activity early may be critical for success, as MPS VII mice with relatively low serum GUSB activity (0.05- to 5-fold normal) [24-26] and MPS I mice with relatively low serum IDUA activity (5-fold normal) [27] at 1 month or later after neonatal AAV vector-mediated gene therapy appeared to have a better therapeutic effect than mice that received a retroviral vector and achieved similar enzyme activity at late times [21-23].

\subsection{Systemic gene therapy in adult mice}

Because most patients are not diagnosed at birth, it is important to test if gene therapy can be effective in older animals. However, immune responses have presented a problem, as is discussed in more detail below. i.v. injection of a retroviral vector into adult immunosuppressed MPS I mice had a marked effect on disease in brain, bone, eye and ear [28], as summarized in Table 2 . The failure to correct disease in the aorta was likely due to lower serum IDUA activity (40-fold normal) than was achieved after neonatal gene therapy, 
and the fact that the aorta is a very difficult site to correct. i.v. injection of an AAV vector to adult MPS II mice improved bone disease [14].

\section{Systemic gene therapy in large animals}

The clinical efficacy of gene therapy in large animal models is likely to be predictive of results in humans, as their larger size requires efficiently scaling, and their longer lifespan allows late efficacy and toxicity to be evaluated. A summary of the results of gene therapy in large animals is shown in Table 3. Untreated MPS VII dogs cannot stand beyond 6 months of age and have severe cardiac disease, corneal clouding and pathologic evidence of lysosomal storage in the brain. MPS VII dogs that received neonatal i.v. injection of a retroviral vector with the human $a_{1}$-antitrypsin promoter achieved a mean of $75 \%$ normal GUSB activity in serum and had profound improvements in most manifestations, including brain lesions, aorta and heart physiology, corneal clouding and bone disease [29-32]. At 6.5 years after therapy, serum GUSB activity remains stable (Figure 1), echocardiograms are normal, and there is little or no corneal clouding (Meg Sleeper, Gustavo Aguirre, ME Haskins and KP Ponder, unpublished data). All animals can still run, although most have an abnormal gait due to hip problems, and radiographs show some abnormalities in bone and cartilage, particularly in the cervical spine. One animal with very high serum IDUA activity (70-fold normal) appeared similar clinically to those with $75 \%$ of normal activity. Similarly, MPS I dogs that achieved 2-fold to 64-fold normal IDUA activity in serum after neonatal i.v. injection of a retroviral vector had marked improvement in most lesions, although the aorta was only partially corrected in one animal with low serum IDUA activity [33]. There have been no adverse effects in either model to date.

\section{Local injections of vector}

Local injection of an AAV2 vector with an EF1a (elongation factor 1a) promoter into the liver resulted in high expression and a therapeutic effect in a number of organs, including the brain, in MPS VII mice [34]. This was probably due to secretion of enzyme from hepatocytes and uptake of enzyme from blood. In theory, transduced non-hepatic cells could also secrete the therapeutic protein into blood, resulting in correction of disease. However, transduction of muscle with a GUSB-expressing AAV vector did not result in high levels of enzyme in blood in mice, which may be due to the large size of the tetrameric protein $(\sim 300$ $\mathrm{kDa}$ ) and the barriers to diffusion [35]. Similarly, implantation of modified cells has not been very effective in vivo in mice for MPS II [36] or MPS VII [37,38], Implantation of modified fibroblasts in MPS VII dogs [39] or myoblasts in MPS I dogs [40] was also relatively ineffective.

\section{Hematopoietic stem cell-directed gene therapy}

HSC-directed gene therapy could result in secretion of enzyme into blood, or migration of modified blood cells into organs which then secrete enzyme locally. This involves ex vivo modification of autologous HSC, which are infused after administration of partial or complete bone marrow ablation to create space for the modified cells. The use of autologous cells avoids the risk of graft-versus-host disease and does not require identification of a compatible donor. HSC-directed gene therapy has only been effective with integrating vectors, as other vectors are lost during the extensive proliferation that occurs. In 1992, Wolfe et al. originally reported that HSC-directed gene therapy could reduce lysosomal storage in liver [41]. This approach has recently been extended to ex vivo transduction of human HSCs that were implanted into immunodeficient MPS VII mice, which reduced lysosomal storage in the liver and spleen. However, this approach failed to reduce lysosomal storage in the brain and eye [42], which may be due to the relatively low transduction efficiency. HSC-directed gene therapy has partially reduced the manifestations of MPS I 
[43] and MPS IIIB [44] in the kidney and brain in animal models, which was attributed to migration of cells into these organs.

In the MPS I dog, HSC-directed gene therapy at 2-12 months of age with the canine IDUA cDNA was not successful, which was attributed to an immune response [45]. HSC-directed gene therapy to fetal MPS I dogs was also not successful, which was probably due to a low degree of transduction and/or low expression $[46,47]$.

\section{Gene correction}

An alternative approach to delivery of a functional copy of a gene is to correct mutations in the endogenous gene. One study involved i.v. injection of an AAV vector that contained single-stranded DNA that was capable of correcting the single base pair deletion present in the endogenous mutant GUSB gene into MPS VII mice [48]. Although the efficiency in this study was too low to result in disease correction, this approach would maintain the appropriate regulation of the gene, and the risk of insertional mutagenesis by integration adjacent to an oncogene would be prevented. It this efficiency could be increased, this would be an ideal approach to gene therapy.

\section{Effect on brain disease with systemic or hematopoietic stem cell- directed gene therapy}

The effect of gene therapy on lysosomal storage in the brain and neurologic function is a very important issue. It has been long-standing dogma that i.v. administration of enzyme would not improve brain disease due to the inability of enzyme to cross the blood-brain barrier (BBB). However, recent studies have refuted this theory. The most compelling data are from the study by Vogler et al. [49], in which i.v. administration of very high doses of GUSB to adult MPS VII mice resulted in $2.5 \%$ of normal GUSB activity in the brain, and reduced storage in neurons. In addition, the finding that lysosomal storage in brain can be reduced with systemic or intrahepatic gene therapy without detectible vector copies in the brain $[26-28,34]$ supports the hypothesis that some enzyme in blood can cross the BBB if levels are sufficiently high. It is also possible that correction in brain after systemic gene therapy is due to expression within the brain. Indeed, neonatal i.v. injection of a lentiviral vector resulted in transduction of neurons in mice [50], whereas i.v. injection of a retroviral vector into newborn dogs resulted in the presence of expressing cells in the brain, although it was unclear if these were blood derived [32,33]. As noted above, transduction of blood cells can also reduce storage in the brain $[43,44]$, which is likely due to migration of blood cells into brain.

\section{Direct injection into brain in mice}

An alternative approach to the treatment of brain disease is to inject a vector directly into the brain. Initial studies focused on achieving high levels of enzyme and reducing pathologic evidence of lysosomal storage; later studies have tested if this could improve neurologic function. In most cases, the reduction in storage extended far beyond the region of transduction, which is probably because of diffusion and/or secretion of lysosomal enzymes after axonal transport from one region to another [51-53]. In addition, biodistribution could be improved by the addition of a protein transduction domain that allowed proteins to enter cells in a M6P-independent fashion [54].

The striatum is a part of the basal ganglia that is located deep within the brain and plays an important role in cognition and coordination. As the striatum has numerous connections with the cortex, the hypothesis was that injection into the striatum would result in delivery of 
enzyme to large regions of the brain via axonal transport. Intrastriatal injections with AAV vectors resulted in enzyme activity and/or reduced lysosomal storage in mice with MPS I [55], MPS IIIB [56] and MPS VII [57,58], and injections of an adenoviral [59] or lentiviral [60] vector was effective for MPS VII. AAV5 vectors were more efficient than AAV2 vectors after intrastriatal injection in mice $[55,56]$, but were not effective in this or other regions of the brain in cats [61].

The lateral ventricles are large fluid-filled structures that extend throughout the cerebrum and wrap around the basal ganglia. As they are relatively close to most cortical regions, the hypothesis was that enzyme in the ventricles might diffuse throughout much of the brain via the cerebrospinal fluid. Indeed, injection of the lateral ventricle with an AAV [62-64] or an adenoviral $[65,66]$ vector resulted in enzyme activity and/or reduced storage in MPS VII mice. Injection of the lateral ventricle with bone marrow stromal cells that were transduced ex vivo with a retroviral vector resulted in cells with enzyme activity in the olfactory bulb, striatum and cerebral cortex, and reduction in disease manifestations [67].

Other approaches to treat the brain have included injecting the vector into the thalamus, cortex or intrathecal space. The thalamus is adjacent to the third ventricle deep within the brain and has numerous connections with the cerebral cortex. An AAV2 vector reduced storage after injection into the thalamus of MPS IIIB mice [68]. Injection of an HSV vector into multiple sites, such as the striatum, thalamus, and hypothalamus [69], multiple injections of a lentiviral vector into the cerebral hemispheres and the cerebellum [70], or injections of an AAV vector into the cortex and hippocampus [71] reduced lysosomal storage in the brain in MPS VII mice. The intrathecal space is the region that surrounds the spinal canal, and connects with the ventricles of the brain. Intrathecal injection of AAV vectors reduced pathologic lesions in the brain in MPS I [72] and MPS VII [73] mice. An important advantage to this approach is that intrathecal injections are minimally invasive and are frequently performed in patients.

As the ultimate goal of gene therapy to the brain is to improve neurologic function, studies that highlight functional improvements in mice after injection into the brain are summarized in Table 4. It is very exciting that a variety of approaches can improve neurologic function, and in some cases this can occur after deficits have already developed. For example, in one study, MPS VII mice had substantial deficits in repeated acquisition and performance chamber analysis at 4 months of age. Administration of a lentiviral vector to the striatum of MPS VII mice at that age resulted in functional improvement in this assay when they were analyzed 1 month later [60].

\section{Direct injection into brain in large animals}

It will be very important to demonstrate that local injections can be effective in large animals where the brain is much bigger. The only study that has been reported that used local injection of a vector into the brain for a large animal model of MPS involved two injections per hemisphere, one into the putamen and the other into the centrum semiovale. The putamen is a component of the striatum, and the centrum semiovale is a region of white matter. This study injected an AAV5 vector with the human IDUA cDNA and a cytomegalovirus (CMV) promoter into MPS I dogs at $\sim 4$ months of age. This resulted in enzyme throughout much of the brain, and reduced biochemical and pathologic evidence of lysosomal storage several months later [74]. It was not possible to assess the effect on cognition, as untreated dogs were not obviously impaired at this age. However, immune responses resulted in inflammation and a loss of expression unless immunosuppression was given. Thus, although intracerebral injections need a complicated imaging and injection 
apparatus to ensure that the vector is delivered to the appropriate place, this approach is feasible and can reduce lysosomal storage in brains of large animals.

\section{Effect on eye disease}

Patients with MPS can develop corneal clouding and/or retinal degeneration, resulting in reduced visual acuity. Many of the studies with systemic gene therapy have resulted in improved visual function on electroretinogram and/or reduced clinical or pathologic evidence of disease in the eye, as summarized in Table 2 . This is probably due to diffusion of the enzyme into the critical regions of the eye, and requires relatively high serum enzyme activity. Other approaches have involved local injection. For MPS VII mice, injection of an AAV2 vector with the CMV- $\beta$-actin promoter into the vitreous improved retinal function and pathology [75], injection of an adenoviral vector with the CMV- $\beta$-actin promoter into the anterior chamber or intrastromal region of the cornea reduced corneal clouding [76], and injection of an adenoviral vector with the RSV promoter into the vitreous or subretinal region reduced lysosomal storage in the retina [77]. In MPS VI cats, subretinal injection of an AAV2 vector with the CMV- $\beta$-actin promoter resulted in marked reduction in pathologic lesions in the retina [78].

\section{Immunologic responses after gene therapy}

Immune responses pose a major hurdle for successful gene therapy. This can be due to cytotoxic T lymphocyte (CTL) or antibody responses, and can be directed against the vector or the therapeutic protein. Immune responses to the therapeutic protein are more likely to occur in patients with null mutations than in those with missense mutations, and null mutations are common in MPS syndromes. For example, the most common mutations in severe MPS I are W402X and Q70X [79], where X represents a stop codon at the indicated position.

CTL immune responses are generally reduced in mice after neonatal gene therapy, which is presumably due to the immaturity of the newborn immune system. Indeed, neonatal gene therapy has resulted in stable expression from retroviral, AAV or lentiviral vectors. Higher doses of a retroviral vector in newborns were more effective at preventing a CTL response than lower doses [80], which may have implications for how to implement a gene therapy trial. CTL responses have been a significant problem after gene therapy to adult MPS I mice [81]. These have been reduced with immunosuppressive agents [28], or with a vector design that uses a liver-specific promoter to reduce expression in antigen-presenting cells [82]. In addition, CTL responses to other genes have been reduced by incorporating a micro RNA (miRNA) sequence into the vector that results in degradation of the mRNA in antigenpresenting cells [83]. Antibody responses have been documented after gene therapy to adult MPS VII mice with retroviral [84], adenoviral [59,85] or plasmid [19] vectors, and these could be delayed or prevented with immunosuppressive agents.

Large animals appear to mount a more potent immunologic response to foreign proteins than mice. Indeed, neonatal administration of a retroviral vector to MPS I cats resulted in a CTL response, which could be prevented with transient administration of the immunosuppressive agent CLTA4-Ig [80]. Immune responses were not observed after neonatal administration of a retroviral vector expressing canine IDUA to MPS I dogs [33], although antibodies developed after myoblast-directed [40] or HSC-directed [45] gene therapy in adult MPS I dogs. Antibody and possibly CTL responses developed in MPS I dogs that received intracranial injection of an AAV vector expressing human IDUA [74]. This resulted in substantial inflammation in the brain, which could be prevented with immunosuppression. 


\section{Potential adverse effects of gene therapy}

Vectors that integrate into the chromosome can upregulate adjacent genes by their enhancer elements, or inactivate tumor-suppressor genes. Indeed, ex vivo HSC-directed gene therapy has resulted in leukemia in $\sim 20 \%$ of patients with severe combined immunodeficiency (SCID) [86], a disease due to deficiency of the common $\gamma$-chain of cytokine receptors, as was recently reviewed by Nienhuis et al. [87]. Many believe that this frequency was due to the specific gene and disease, as leukemia has not developed in other gene therapy trials. Liver tumors were reported in $>50 \%$ of mice that received fetal or neonatal transfer of an equine infectious anemia virus (EIAV)-based lentiviral vector [88]. These investigators did not see tumors in animals that received other lentiviral vectors or $\gamma$-retroviral vectors, suggesting that a specific element in the EIAV lentiviral vector functioned as an oncogene. This incidence has not been seen in other gene therapy trials in liver with retroviral vectors. Retroviral vectors that have a deletion in the enhancer region of the long-terminal repeats (so-called self-inactivating retroviral vectors) have a reduced chance of activating the expression of adjacent genes [89,90], and will probably be preferred for clinical trials in the future. An alternative approach to increase safety might be to achieve site-specific integration, as has been achieved for plasmid vectors with tranposable elements [91].

Tumors developed at late times in $\sim 50 \%$ of MPS VII mice that received neonatal injection of an AAV2 vector $[92,93]$. In some cases, tumors had AAV sequences integrated within a small region on chromosome 12, which was associated with upregulation of miRNA genes within that locus [93]. Although tumors due to an AAV vector per se have not been reported in other AAV trials, few have involved neonatal transduction with long-term evaluation. Elements that could insulate adjacent sequences from enhancement [94] or could promote death of the cell if needed [95] are being developed, and could improve the safety of any vector.

Another concern of gene therapy has been the possibility of germline transmission. Indeed, systemic administration of retroviral [96] and AAV [97] vectors resulted in the transient appearance of vector sequences in the semen of some patients, which cleared over time. Neonatal i.v. injection of a retroviral vector into male MPS VII dogs has not resulted in germline transmission in any of 629 puppies that have been analyzed to date (ME Haskins, KP Ponder, unpublished data). Thus, it appears that the chance of germline transmission is low with systemic approaches, which is likely to be due in part to the barriers that prevent vectors from reaching germ cells from blood, but could also relate to the failure of AAV vectors to integrate efficiently, and the failure of $\gamma$-retroviral vectors to transduce nondividing germ cells in newborns. It is unlikely that ex vivo transduction of hematopoietic stem cells or direct injection of a vector into an isolated site such as the brain would result in germline transmission.

\section{Newborn screening}

Treatments for MPS are most effective if applied as early as possible. However, early treatment would require that patients be identified at or shortly after birth. Recent progress in techniques for newborn diagnosis of MPS appear very promising [98,99], and it is very likely that routine screening of newborns for some or all of these disorders will be initiated within the next decade.

\section{Conclusion}

Gene therapy has many advantages as a treatment for MPS. Systemic administration of $\gamma-$ retroviral, lentiviral, AAV, adenoviral and plasmid vectors have all resulted in a substantial amelioration of many of the clinical manifestations of the MPS disorders, which is probably 
due primarily to secretion of enzyme into blood that diffuses to other organs and is taken up via the M6PR. Many organs such as liver, spleen and lung are readily corrected. The aorta, bone, cartilage, eye and brain are more difficult to correct, which may reflect inadequate diffusion into these sites or low expression of the M6PR. Brain disease has also been effectively treated with localized gene therapy. This has involved injection into the striatum, the lateral ventricle, the thalamus, cortex, hippocampus or cerebrospinal fluid, and has reduced pathologic lesions in brain and/or improved neurologic function.

\section{Expert opinion}

Systemic gene therapy with a variety of vectors has been successful in several MPS syndromes, and it is reasonable that this very simple approach could be used to treat children with these devastating disorders. However, adenoviral vectors are unlikely to be used clinically in the near future due their ability to induce inflammation and their instability in a growing liver. Although leukemias have developed in one gene therapy trial with $\gamma$ retroviral vectors, this has not occurred in other HSC-directed trials, and the overall risk is almost certainly less than the risk of HSCT, which has a $15 \%$ mortality. Present studies are attempting to define the risk of neoplasia, and to modify vectors to reduce their carcinogenic potential. As we believe that the leukemias that developed after ex vivo HSC-directed gene therapy in patients of X-linked SCID are due, in part, to the transgene and the specific model, it is our opinion that clinical trials with $\gamma$-retroviral vectors or lentiviral vectors should be considered if there are reasonable safety data in animals. There was a high incidence of liver tumors after neonatal administration of AAV vectors in one study that remains unexplained and will need to be evaluated further prior to initiating clinical trials. HSC-directed gene therapy has not been as effective as systemic gene therapy to date; it has documented leukemogenic potential in patients with X-linked SCID, and would likely require some level of bone marrow ablation to achieve success. Nevertheless, there is a track record of efficacy of HSC-directed gene therapy for other genetic diseases, and HSCT has efficacy for MPS. Thus, this remains a viable approach for the future.

Disorders with neurologic manifestations pose separate ethical and therapeutic issues from those that are dominated by systemic symptoms. Although it has been long-standing dogma that enzyme in blood would not reach the brain at clinically significant levels, there are very exciting data suggesting that achieving very high levels of enzyme in blood can reduce lysosomal storage in the brain. There are also many studies that demonstrate that local injection into brain results in substantial enzyme activity and a reduction in lysosomal storage throughout much of the brain, and can improve neurologic function. Although some of these injection procedures appear to be draconian, it is very reasonable to consider that a limited number of injections could be performed once in patients using vectors that exhibit stable expression over time. The efficacy of intrathecal injection of vector into the lumbar region is exciting, as this simple and commonly used procedure could readily be performed in patients. It is also possible that a combination of two different gene therapy approaches, or a combination of gene therapy with an established treatment, will result in a more effective treatment than a single approach alone. Overall, there is great hope that gene therapy could be effective for this class of diseases in the relatively near future.

\section{Acknowledgments}

The authors thank M Sands for helpful suggestions on the manuscript. This work was supported by DK066448 awarded to KP Ponder and RR02512, DK25759, DK54481 awarded to ME Haskins. 


\section{Bibliography}

Papers of special notes have been highlighted as either of interest $(\bullet)$ or of considerable interest $(\bullet)$ to readers.

1. NEUFELD, EF.; MUENZER, J. The mucopolysaccharidoses. In: Scriver, CR.; Beaudet, AL.; Sly, WS.; Valle, D., editors. Metabolic and Molecular Basis of Inherited Disease. McGraw Hill; New York, USA: 2001. p. 3421-3452.

2. BAEHNER F, SCHMIEDESKAMP C, KRUMMENAUER F, et al. Cumulative incidence rates of the mucopolysaccharidoses in Germany. J Inherit Metab Dis. 2005; 28(6):1011-1017. [PubMed: 16435194]

3. DESNICK RJ. Enzyme replacement and enhancement therapies for lysosomal diseases. J Inherit Metab Dis. 2004; 27(3):385-410. [PubMed: 15190196]

4. HOOGERBRUGGE PM, BROUWER OF, BORDIGONI P, et al. Allogeneic bone marrow transplantation for lysosomal storage diseases. The European group for bone marrow transplantation. Lancet. 1995; 345(8962):1398-1402. [PubMed: 7760610]

5. SIFUENTES M, DOROSHOW R, HOFT R. A follow-up study of MPS I patients treated with laronidase enzyme replacement therapy for 6 years. Mol Genet Metab. 2007; 90(2):171-180. [PubMed: 17011223]

6. MUENZER J, WRAITH JE, BECK M, et al. A Phase II/III clinical study of enzyme replacement therapy with idursulfase in mucopolysaccharidosis II (Hunter syndrome). Genet Med. 2006; 8(8): 465-473. [PubMed: 16912578]

7. HARMATZ P, GIUGLIANI R, SCHWARTZ I, et al. Enzyme replacement therapy for mucopolysaccharidosis VI: a Phase III, randomized, double-blind, placebo-controlled, multinational study of recombinant human $N$-acetylgalactosamine 4-sulfarase (recombinant human arylsulfatase B or rhASB) and follow-on, open-label extension study. J Pediatr. 2006; 148(4):533-539. [PubMed: 16647419]

8. PETERS C, SHAPIRO EG, ANDERSON J, et al. Hurler syndrome. II. Outcome of HLAgenotypically identical sibling and HLA-haploidentical related donor bone marrow transplantation in fifty-four children. The storage disease collaborative study group. Blood. 1998; 91(7):26012608. [PubMed: 9516162]

9. STABA SL, ESCOLAR ML, POE M, et al. Cord-blood transplants from unrelated donors in patients with Hurler's syndrome. N Engl J Med. 2004; 350(19):1960-1969. [PubMed: 15128896]

10. VELLODI A, YOUNG E, COOPER A, LIDCHI V, WINCHESTER B, WRAITH JE. Long-term follow-up following bone marrow transplantation for Hunter disease. J Inherit Metab Dis. 1999; 22(5):638-648. [PubMed: 10399096]

11. ERSKHOVITZ E, YOUNG E, RAINER J, et al. Bone marrow transplantation for MaroteauxLamy syndrome (MPS VI): long-term follow-up. J Inherit Metab Dis. 1999; 22(1):50-62. [PubMed: 10070618]

12. SARDIELLO M, ANNUNZIATA I, ROMA G, BALLABIO A. Sulfatases and sulfatase modifying factors: an exclusive and promiscuous relationship. Hum Mol Genet. 2005; 14(21):3203-3217. [PubMed: 16174644]

13. FRALDI A, BIFFI A, LOMBARDI A, et al. SUMF1 enhances sulfatase activities in vivo in five sulfatase deficiencies. Biochem J. 2007; 403(2):305-312. This paper shows that co-expression of SUMF1 with the sulfatase that is deficient in MPS IIIA augments the production of functional enzyme in mice. [PubMed: 17206939]

14. CARDONE M, POLITO VA, PEPE S, et al. Correction of Hunter syndrome in the MPSII mouse model by AAV2/8-mediated gene delivery. Hum Mol Genet. 2006; 15(7):1225-1236. This paper shows that intravenous injection of an AAV2 vector expressing iduronate 2-sulfatase can result in high serum enzyme activity and reduce bone disease and brain pathology in MPS II mice. [PubMed: 16505002]

15. YOUNG LS, SEARLE PF, ONION D, MAUTNER V. Viral gene therapy strategies: from basic science to clinical application. J Pathol. 2006; 208(2):299-318. [PubMed: 16362990]

16. HODGES BL, CHENG SH. Cell and gene-based therapies for the lysosomal storage diseases. Curr Gene Ther. 2006; 6(2):227-241. [PubMed: 16611044] 
17. ELLINWOOD NM, VITE CH, HASKINS ME. Gene therapy for lysosomal storage diseases: the lessons and promise or animal models. J Gene Med. 2004; 6(5):481-506. [PubMed: 15133760]

18. CHEN ZY, HE CY, EHRHARDT A, KAY MA. Minicircle DNA vectors devoid of bacterial DNA result in persistent and high-level transgene expression in vivo. Mol Ther. 2003; 8(3):495-500. [PubMed: 12946323]

19. ARONOVICH EL, BELL JB, BELUR LR, et al. Prolonged expression of a lysosomal enzyme in mouse liver after sleeping beauty transposon-mediated gene delivery: implications for non-viral gene therapy of mucopolysaccharidoses. J Gene Med. 2007; 9(5):403-415. [PubMed: 17407189]

20. SANDS MS, DAVIDSON BL. Gene therapy for lysosomal storage diseases. Mol Ther. 2006; 13(5):839-849. [PubMed: 16545619]

$21 \bullet$. XU L, MANGO RL, SANDS MS, HASKINS ME, ELLINWOOD NM, PONDER KP. Evaluation of pathological manifestations of disease in mucopolysaccharidosis VII mice after neonatal hepatic gene therapy. Mol Ther. 2002; 6(6):745-758. This paper evaluates the serum GUSB activity needed to prevent various manifestations of disease in MPS VII mice after neonatal retroviral vector-mediated gene therapy. [PubMed: 12498771]

22••. LIU Y, XU L, HENNIG AK, et al. Liver-directed neonatal gene therapy prevents cardiac, bone, ear, and eye disease in mucopolysaccharidosis I mice. Mol Ther. 2005; 11(1):35-47. This paper shows that neonatal intravenous injection of a retroviral vector can result in high serum IDUA activity and completely correct clinical and pathological manifestations in many organs in MPS I. [PubMed: 15585404]

23••. CHUNG S, MA X, LIU Y, LEE D, TITTIGER M, PONDER KP. Effect of neonatal administration of a retroviral vector expressing a-1-iduronidase upon lysosomal storage in brain and other organs in mucopolysaccharidosis I mice. Mol Genet Metabol. 2007; 90(2):181-192. This paper shows that neonatal intravenous injection of a retroviral vector can completely correct pathologic manifestations of disease in brain of MPS I mice.

24••. DALYTM, OHLEMILLER KK, ROBERTS MS, VOGLER CA, SANDS MS. Prevention of systemic clinical disease in MPS VII mice following AAV-mediated neonatal gene transfer. Gene Ther. 2001; 8(17):1291-1298. This paper demonstrates that neonatal gene therapy with an AAV vector results in partial improvements in body weights, bone, and eye and ear function in MPS VII mice. [PubMed: 11571565]

25•. DALYTM, VOGLER C, LEVY B, HASKINS ME, SANDS MS. Neonatal gene transfer leads to widespread correction of pathology in a murine model of lysosomal storage disease. Proc Natl Acad Sci USA. 1999; 96(5):2296-2300. This paper demonstrates that neonatal gene therapy with an AAV vector results in partial improvements in MPS VII mice even with relatively low serum GUSB activity. [PubMed: 10051635]

26. DONSANTE A, LEVY B, VOGLER C, SANDS MS. Clinical response to persistent, low-level $\beta$ glucuronidase expression in the murine model of mucopolysaccharidosis type VII. J Inherit Metab Dis. 2007; 30(2):227-238. [PubMed: 17308887]

$27 \bullet$. HARTUNG SD, FRANDSEN JL, PAN D, et al. Correction of metabolic, craniofacial, and neurologic abnormalities in MPS I mice treated at birth with adeno-associated virus vector transducing the human a-L-iduronidase gene. Mol Ther. 2004; 9(6):866-875. This paper demonstrates that neonatal gene therapy with an AAV vector results in reduction in brain and bone disease in MPS I mice and that vector copies are not detectable in brain. [PubMed: 15194053]

28••. MA X, LIU Y, TITTIGER M, et al. Improvements in mucopolysaccharidosis I mice after adult retroviral vector-mediated gene therapy with immunomodulation. Mol Ther. 2007; 15:889-902. This paper demonstrates that gene therapy to adult MPS I mice results in improvements in hearing, vision, bone, and in brain pathology. [PubMed: 17311010]

29••. PONDER KP, MELNICZEK JR, XU L, et al. Therapeutic neonatal hepatic gene therapy in mucopolysaccharidosis VII dogs. Proc Natl Acad Sci USA. 2002; 99(20):13102-13107. This paper demonstrates that neonatal gene therapy with a retroviral vector results in improvements in heart, bone, body weights, and mobility in MPS VII dogs. [PubMed: 12232044]

30. SLEEPER MM, FORNASARI B, ELLINWOOD NM, et al. Gene therapy ameliorates cardiovascular disease in dogs with mucopolysaccharidosis VII. Circulation. 2004; 110(7):815820. [PubMed: 15289379] 
31. MANGO RL, XU L, SANDS MS, et al. Neonatal retroviral vector-mediated hepatic gene therapy reduces bone, joint, and cartilage disease in mucopolysaccharidosis VII mice and dogs. Mol Genet Metab. 2004; 82(1):4-19. [PubMed: 15110316]

32. WANG B, OMALLEYTM O, XU L, et al. Expression in blood cells may contribute to biochemical and pathological improvements after neonatal intravenous gene therapy for mucopolysaccharidosis VII in dogs. Mol Genet Metab. 2006; 87(1):8-21. [PubMed: 16275036]

33••. TRAAS AM, WANG P, MA X, et al. Correction of clinical manifestations of canine mucopolysaccharidosis I with neonatal retroviral vector gene therapy. Mol Ther. 33:1423-1431. This paper demonstrates that neonatal gene therapy with a retroviral vector to MPS I dogs results in improvements in brain, aorta and eye.

34••. SFERRA TJ, BACKSTROM K, WANG C, RENNARD R, MILLER M, HU Y. Widespread correction of lysosomal storage following intrahepatic injection of a recombinant adenoassociated virus in the adult MPS VII mouse. Mol Ther. 2004; 10(3):478-491. This paper demonstrates that local gene therapy to the liver of adult MPS VII mice results in high serum GUSB activity and reduction in brain pathology without detectable vector copies in brain. [PubMed: 15336648]

35. DALYTM, OKUYAMA T, VOGLER C, HASKINS ME, MUZYCZKA N, SANDS MS. $\beta$ glucuronidase expression in situ and correction of liver pathology in mucopolysaccharidosis type VII mice. Hum Gene Ther. 1999; 10(1):85-94. [PubMed: 10022533]

36. FRISO A, TOMANIN R, ALBA S, et al. Reduction of GAG storage in MPS II mouse model following implantation of encapsulated recombinant myoblasts. J Gene Med. 2005; 7(11):14821491. [PubMed: 15966019]

37. ROSS CJ, BASTEDO L, MAIER SA, SANDS MS, CHANG PL. Treatment of a lysosomal storage disease, mucopolysaccharidosis VII, with microencapsulated recombinant cells. Hum Gene Ther. 2000; 11(15):2117-2127. [PubMed: 11044913]

38. MOULLIER P, BOHL D, HEARD JM, DANOS O. Correction of lysosomal storage in the liver and spleen of MPS VII mice by implantation of genetically modified skin fibroblasts. Nat Genet. 1993; 4(2):154-159. [PubMed: 8348154]

39. WOLFE JH, SANDS MS, HAREL N, et al. Gene transfer of low levels of $\beta$-glucuronidase corrects hepatic lysosomal storage in a large animal model of mucopolysaccharidosis VII. Mol Ther. 2000; 2(6):552-561. [PubMed: 11124056]

40. SHULL RM, LU X, MCENTEE MF, BRIGHT RM, PEPPER KA, KOHN DB. Myoblast gene therapy in canine mucopolysaccharidosis. I: abrogation by an immune response to a-Liduronidase. Hum Gene Ther. 1996; 7(13):1595-1603. [PubMed: 8864760]

41. WOLFE JH, SANDS MS, BARKER JE, et al. Reversal of pathology in murine mucopolysaccharidosis type VII by somatic cell gene transfer. Nature. 1992; 360(6406):749-753. [PubMed: 1465145]

42•. HOFLING AA, DEVINE S, VOGLER C, SANDS MS. Human CD34 ${ }^{+}$hematopoietic progenitor cell-directed lentiviral-mediated gene therapy in a xenotransplantation model of lysosomal storage disease. Mol Ther. 2004; 9(6):856-865. This paper demonstrates that transduction of hematopoietic stem cells from a human patient with MPS VII results in some pathological improvements after transplantation of modified cells into immunodeficient MPS VII mice. [PubMed: 15194052]

43. ZHENG Y, ROZENGURT N, RYAZANTSEV S, KOHN DB, SATAKE N, NEUFELD EF. Treatment of the mouse model of mucopolysaccharidosis I with retrovirally transduced bone marrow. Mol Genet Metab. 2003; 79(4):233-244. [PubMed: 12948739]

44•. ZHENG Y, RYAZANTSEV S, OHMI K, et al. Retrovirally transduced bone marrow has a therapeutic effect on brain in the mouse model of mucopolysaccharidosis IIIB. Mol Genet Metab. 2004; 82(4):286-295. This paper demonstrates that transduction of HSCs can result in reduction in storage in the brain in MPS IIIB mice. [PubMed: 15308126]

45. LUTZKO C, KRUTH S, ABRAMS-OGG AC, et al. Genetically corrected autologous stem cells engraft, but host immune responses limit their utility in canine a-L-iduronidase deficiency. Blood. 1999; 93(6):1895-1905. [PubMed: 10068662]

46. LUTZKO C, OMORI F, ABRAMS-OGG AC, et al. Gene therapy for canine a-L-iduronidase deficiency: in utero adoptive transfer of genetically corrected hematopoietic progenitors results in 
engraftment but not amelioration of disease. Hum Gene Ther. 1999; 10(9):1521-1532. [PubMed: 10395377]

47. MEERTENS L, ZHAO Y, ROSIC-KABLAR S, et al. In utero injection of a-L-iduronidasecarrying retrovirus in canine mucopolysaccharidosis type I: infection of multiple tissues and neonatal gene expression. Hum Gene Ther. 2002; 13(15):1809-1820. [PubMed: 12396614]

48. MILLER DG, WANG PR, PETEK LM, HIRATA RK, SANDS MS, RUSSELL DW. Gene targeting in vivo by adeno-associated virus vectors. Nat Biotechnol. 2006; 24(8):1022-1026. [PubMed: 16878127]

49••. VOGLER C, LEVY B, GRUBB JH, et al. Overcoming the blood-brain barrier with high-dose enzyme replacement therapy in murine mucopolysaccharidosis VII. Proc Natl Acad Sci USA. 2005; 102(41):14777-14782. This paper demonstrates that injection of high doses of GUSB can result in reduction in storage in the brain, and suggest that the BBB does not preclude enzyme from reaching the brain. [PubMed: 16162667]

$50 \bullet$. KOBAYASHI H, CARBONARO D, PEPPER K, et al. Neonatal gene therapy of MPS I mice by intravenous injection of a lentiviral vector. Mol Ther. 2005; 11:776-789. This paper demonstrates that neonatal injection of a lentiviral vector can result in transduction of cells in the brain and reduce lysosomal storage in brain and in bone. [PubMed: 15851016]

51••. HENNIG AK, LEVY B, OGILVIE JM, et al. Intravitreal gene therapy reduces lysosomal storage in specific areas of the CNS in mucopolysaccharidosis VII mice. J Neurosci. 2003; 23(8):33023307. This paper demonstrates that transduction of eye can result in enzyme in regions with neurological connections to the eye. [PubMed: 12716937]

52••. CHEN F, VITRY S, HOCQUEMILLER M, DESMARIS N, AUSSEIL J, HEARD JM. a-Liduronidase transport in neurites. Mol Genet Metab. 2006; 87(4):349-358. This paper demonstrated that IDUA can be transported from one region of the brain to another via neurons. [PubMed: 16439176]

53••. PASSINI MA, LEE EB, HEUER GG, WOLFE JH. Distribution of a lysosomal enzyme in the adult brain by axonal transport and by cells of the rostral migratory stream. J Neurosci. 2002; 22(15):6437-6446. This paper shows that GUSB can be widely distributed throughout the brain of MPS VII mice by neuronal connections. [PubMed: 12151523]

54. XIA H, MAO Q, DAVIDSON BL. The HIV Tat protein transduction domain improves the biodistribution of $\beta$-glucuronidase expressed from recombinant viral vectors. Nat Biotechnol. 2001; 19(7):640-644. [PubMed: 11433275]

55. DESMARIS N, VEROT L, PUECH JP, CAILLAUD C, VANIER MT, HEARD JM. Prevention of neuropathology in the mouse model of Hurler syndrome. Ann Neurol. 2004; 56(1):68-76. [PubMed: 15236403]

56••. CRESSANT A, DESMARIS N, VEROT L, et al. Improved behavior and neuropathology in the mouse model of Sanfilippo type IIIB disease after adeno-associated virus-mediated gene transfer in the striatum. J Neurosci. 2004; 24(45):10229-10239. This paper demonstrates that direct injection an AAV vector into the striatum of MPS IIIB mice can result in improved behavior and neurologic function. [PubMed: 15537895]

57. BOSCH A, PERRET E, DESMARIS N, HEARD JM. Long-term and significant correction of brain lesions in adult mucopolysaccharidosis type VII mice using recombinant AAV vectors. Mol Ther. 2000; 1(1):63-70. [PubMed: 10933913]

58••. LIU G, CHEN YH, HE X, et al. Adeno-associated virus type 5 reduces learning deficits and restores glutamate receptor subunit levels in MPS VII mice CNS. Mol Ther. 2007; 15(2):242247. This paper shows that local injection of an AAV vector to adult MPS VII mice results in improved neurologic function. [PubMed: 17235300]

59. STEIN CS, GHODSI A, DERKSEN T, DAVIDSON BL. Systemic and central nervous system correction of lysosomal storage in mucopolysaccharidosis type VII mice. J Virol. 1999; 73(4): 3424-3429. [PubMed: 10074197]

60. BROOKS AI, STEIN CS, HUGHES SM, et al. Functional correction of established central nervous system deficits in an animal model of lysosomal storage disease with feline immunodeficiency virus-based vectors. Proc Natl Acad Sci USA. 2002; 99(9):6216-6221. [PubMed: 11959904] 
61. VITE CH, PASSINI MA, HASKINS ME, WOLFE JH. Adeno-associated virus vector-mediated transduction in the cat brain. Gene Ther. 2003; 10(22):1874-1881. [PubMed: 14502216]

62••. PASSINI MA, WATSON DJ, VITE CH, LANDSBURG DJ, FEIGENBAUM AL, WOLFE JH. Intraventricular brain injection of adeno-associated virus type 1 (AAV1) in neonatal mice results in complementary patterns of neuronal transduction to AAV2 and total long-term correction of storage lesions in the brains of $\beta$-glucuronidase-deficient mice. J Virol. 2003; 77(12):7034-7040. This paper demonstrates that injection of an AAV vector into the ventricles of MPS VII mice results in reduction in lysosomal storage throughout much of the brain. [PubMed: 12768022]

63••. LIU G, MARTINS I, WEMMIE JA, CHIORINI JA, DAVIDSON BL. Functional correction of CNS phenotypes in a lysosomal storage disease model using adeno-associated virus type 4 vectors. J Neurosci. 2005; 25(41):9321-9327. This paper demonstrates that injection of an AAV vector into the brain results in improved neurologic function in MPS VII mice. [PubMed: 16221840]

64. KAROLEWSKI BA, WOLFE JH. Genetic correction of the fetal brain increases the lifespan of mice with the severe multisystemic disease mucopolysaccharidosis type VII. Mol Ther. 2006; 14(1):14-24. [PubMed: 16624622]

65. GHODSI A, STEIN C, DERKSEN T, MARTINS I, ANDERSON RD, DAVIDSON BL. Systemic hyperosmolality improves $\beta$-glucuronidase distribution and pathology in murine MPS VII brain following intraventricular gene transfer. Exp Neurol. 1999; 160(1):109-116. [PubMed: 10630195]

66. OHASHIT, WATABE K, UEHARA K, SLY WS, VOGLER C, ETO Y. Adenovirus-mediated gene transfer and expression of human $\beta$-glucuronidase gene in the liver, spleen, and central nervous system in mucopolysaccharidosis type VII mice. Proc Natl Acad Sci USA. 1997; 94(4): 1287-1292. [PubMed: 9037045]

67••. SAKURAI K, IIZUKA S, SHEN JS, et al. Brain transplantation of genetically modified bone marrow stromal cells corrects CNS pathology and cognitive function in MPS VII mice. Gene Ther. 2004; 11 (19):1475-1481. This paper demonstrates that injection of genetically modified cells into the lateral ventricles can improve neurological function in MPS VII mice. [PubMed: 15295619]

68. FU H, SAMULSKI RJ, MCCOWN TJ, PICORNELL YJ, FLETCHER D, MUENZER J. Neurological correction of lysosomal storage in a mucopolysaccharidosis IIIB mouse model by adeno-associated virus-mediated gene delivery. Mol Ther. 2002; 5(1):42-49. [PubMed: 11786044]

69. BERGES BK, YELLAYI S, KAROLEWSKI BA, MISELIS RR, WOLFE JH, FRASER NW. Widespread correction of lysosomal storage in the mucopolysaccharidosis type VII mouse brain with a herpes simplex virus type 1 vector expressing $\beta$-glucuronidase. Mol Ther. 2006; 13(5):859869. [PubMed: 16515890]

70. BOSCH A, PERRET E, DESMARIS N, TRONO D, HEARD JM. Reversal of pathology in the entire brain of mucopolysaccharidosis type VII mice after lentivirus-mediated gene transfer. Hum Gene Ther. 2000; 11(8):1139-1150. [PubMed: 10834616]

71••. FRISELLA WA, O'CONNOR LH, VOGLER C, et al. Intracranial injection of recombinant adeno-associated virus improves cognitive function in a murine model of mucopolysaccharidosis type VII. Mol Ther. 2001; 3(3):351-358. This paper demonstrates that local injection of an AAV vector into the hemispheres and hippocampus of MPS VII mice can improve neurological function. [PubMed: 11273777]

72••. WATSON G, BASTACKY J, BELICHENKO P, et al. Intrathecal administration of AAV vectors for the treatment of lysosomal storage in the brains of MPS I mice. Gene Ther. 2006; 13(11): 917-925. This paper shows that intrathecal injection of an AAV vector can reduce lysosomal storage in the cerebellum and brain of MPS I mice. [PubMed: 16482204]

73••. ELLIGER SS, ELLIGER CA, AGUILAR CP, RAJU NR, WATSON GL. Elimination of lysosomal storage in brains of MPS VII mice treated by intrathecal administration of an adenoassociated virus vector. Gene Ther. 1999; 6(6):1175-1178. This paper shows that intrathecal injection of an AAV vector can reduce lysosomal storage in the brain of MPS VII mice. [PubMed: 10455422]

74••. CIRON C, DESMARIS N, COLE MA, et al. Gene therapy of the brain in the dog model of Hurler s syndrome. Ann Neurol. 2006; 60(2):204-213. This paper shows that localized injection

Expert Opin Biol Ther. Author manuscript; available in PMC 2012 May 01. 
in the brain of MPS I dogs can result in reduction in lysosomal storage throughout much of the brain. [PubMed: 16718701]

75. HENNIG AK, OGILVIE JM, OHLEMILLER KK, TIMMERS AM, HAUSWIRTH WW, SANDS MS. AAV-mediated intravitreal gene therapy reduces lysosomal storage in the retinal pigmented epithelium and improves retinal function in adult MPS VII mice. Mol Ther. 2004; 10(1):106-116. [PubMed: 15233947]

76. KAMATA Y, OKUYAMA T, KOSUGA M, et al. Adenovirus-mediated gene therapy for corneal clouding in mice with mucopolysaccharidosis type VII. Mol Ther. 2001; 4(4):307-312. [PubMed: 11592832]

77. LI T, DAVIDSON BL. Phenotype correction in retinal pigment epithelium in murine mucopolysaccharidosis VII by adenovirus-mediated gene transfer. Proc Natl Acad Sci USA. 1995; 92(17):7700-7704. [PubMed: 7644479]

78. HO TT, MAGUIRE AM, AGUIRRE GD, et al. Phenotypic rescue after adeno-associated virusmediated delivery of 4-sulfatase to the retinal pigment epithelium of feline mucopolysaccharidosis VI. J Gene Med. 2002; 4(6):613-621. [PubMed: 12439853]

79. MATTE U, YOGALINGAM G, BROOKS D, et al. Identification and characterization of 13 new mutations in mucopolysaccharidosis type I patients. Mol Genet Metab. 2003; 78(1):37-43. [PubMed: 12559846]

80•• PONDER KP, WANG B, WANG P, et al. Mucopolysaccharidosis I cats mount a cytotoxic T lymphocyte response after neonatal gene therapy that can be blocked with CTLA4-Ig. Mol Ther. 2006; 14(1):5-13. This paper demonstrates that the newborn cat immune system is mature enough to produce a CTL response after neonatal gene therapy, and that this can be prevented with transient administration of an immunosuppressive agent. [PubMed: 16698321]

81. DI DOMENICO C, VILLANI GR, DI NAPOLI D, et al. Gene therapy for a mucopolysaccharidosis type I murine model with lentiviral-IDUA vector. Hum Gene Ther. 2005; 16(1):81-90. [PubMed: 15703491]

82. DI DOMENICO C, DI NAPOLI D, GONZALEZ Y, et al. Limited transgene immune response and long-term expression of human a-L-iduronidase in young adult mice with mucopolysaccharidosis type I by liver-directed gene therapy. Hum Gene Ther. 2006; 17(11):1112-1121. [PubMed: 17044753]

83. BROWN BD, VENNERI MA, ZINGALE A, SERGI SERGI L, NALDINI L. Endogenous microRNA regulation suppresses transgene expression in hematopoietic lineages and enables stable gene transfer. Nat Med. 2006; 12(5):585-591. [PubMed: 16633348]

84. GAO C, SANDS MS, HASKINS ME, PONDER KP. Delivery of a retroviral vector expressing human $\beta$-glucuronidase to the liver and spleen decreases lysosomal storage in mucopolysaccharidosis VII mice. Mol Ther. 2000; 2(3):233-244. [PubMed: 10985954]

85. KOSUGA M, TAKAHASHI S, SASAKI K, et al. Adenovirus-mediated gene therapy for mucopolysaccharidosis VII: involvement of cross-correction in wide-spread distribution of the gene products and long-term effects of CTLA-4Ig coexpression. Mol Ther. 2000; 1(5):406-413. [PubMed: 10933961]

86. BAILEY SI, HOWE SJ, SCHAMBACH A, KINNON C, BAUM C, THRASHER AJ. Novel $\gamma$ retroviral vectors for gene therapy of SCID-X1. Mol Ther. 2006; 13:S256.

87. NIENHUIS AW, DUNBAR CE, SORRENTINO BP. Genotoxicity of retroviral integration in hematopoietic cells. Mol Ther. 2006; 13(6):1031-1049. [PubMed: 16624621]

88. THEMIS M, WADDINGTON SN, SCHMIDT M, et al. Oncogenesis following delivery of a nonprimate lentiviral gene therapy vector to fetal and neonatal mice. Mol Ther. 2005; 12(4):763771. [PubMed: 16084128]

89. MODLICH U, BOHNE J, SCHMIDT M, et al. Cell-culture assays reveal the importance of retroviral vector design for insertional genotoxicity. Blood. 2006; 108(8):2545-2553. [PubMed: 16825499]

90. MONTINI E, CESANA D, SCHMIDT M, et al. Hematopoietic stem cell gene transfer in a tumorprone mouse model uncovers low genotoxicity of lentiviral vector integration. Nat Biotechnol. 2006; 24(6):687-696. [PubMed: 16732270] 
91. CALOS MP. The phiC31 integrase system for gene therapy. Curr Gene Ther. 2006; 6(6):633-645. [PubMed: 17168696]

92. DONSANTE A, VOGLER C, MUZYCZKA N, et al. Observed incidence of tumorigenesis in long-term rodent studies of rAAV vectors. Gene Ther. 2001; 8(17):1343-1346. [PubMed: 11571571]

93. DONSANTE A, MILLER DG, LI Y, et al. AAV vector integration sites in mouse hepatocellular carcinoma. Science. 317:477. [PubMed: 17656716]

94. MALIK P, ARUMUGAM PI, YEE JK, PUTHENVEETIL G. Successful correction of the human Cooley's anemia $\{\beta\}$-thalassemia major phenotype using a lentiviral vector flanked by the chicken hypersensitive site 4 chromatin insulator. Ann NY Acad Sci. 2005; 1054:238-249. [PubMed: 16339671]

95. BLUMENTHAL M, SKELTON D, PEPPER KA, JAHN T, METHANGKOOL E, KOHN DB. Effective suicide gene therapy for leukemia in a model of insertional oncogenesis in mice. Mol Ther. 2007; 15(1):183-192. [PubMed: 17164790]

96. POWELL JS, RAGNI MV, WHITE GC, et al. Phase I trial of FVIII gene transfer for severe hemophilia A using a retroviral construct administered by peripheral intravenous infusion. Blood. 2003; 102(6):2038-2045. [PubMed: 12763932]

97. MANNO CS, PIERCE GF, ARRUDA VR, et al. Successful transduction of liver in hemophilia by AAV-factor IX and limitations imposed by the host immune response. Nat Med. 2006; 12(3):342347. [PubMed: 16474400]

98. MEIKLE PJ, GRASBY DJ, DEAN CJ, et al. Newborn screening for lysosomal storage disorders. Mol Genet Metab. 2006; 88(4):307-314. [PubMed: 16600651]

99. WANG D, EADALA B, SADILEK M, et al. Tandem mass spectrometric analysis of dried blood spots for screening of mucopolysaccharidosis I in newborns. Clin Chem. 2005; 51(5):898-900. [PubMed: 15695324]

100. ANSON DS, MCINTYRE C, THOMAS B, et al. Lentiviral-mediated gene correction of mucopolysaccharidosis type III A. Genet Vaccines Ther. 2007; 5:1. [PubMed: 17227588]

101. ELLIGER SS, ELLIGER CA, LANG C, WATSON GL. Enhanced secretion and uptake of $\beta$ glucuronidase improves adeno-associated viral-mediated gene therapy of mucopolysaccharidosis type VII mice. Mol Ther. 2002; 5(5):617-626. [PubMed: 11991753]

102. KAMATA Y, TANABE A, KANAJI A, et al. Long-term normalization in the central nervous system, ocular manifestations, and skeletal deformities by a single systemic adenovirus injection into neonatal mice with mucopolysaccharidosis VII. Gene Ther. 2003; 10(5):406-414. [PubMed: 12601395]

103. KANAJI A, KOSUGA M, LI XK, et al. Improvement of skeletal lesions in mice with mucopolysaccharidosis type VII by neonatal adenoviral gene transfer. Mol Ther. 2003; 8(5):718725. [PubMed: 14599804] 


\section{Expression in MPS VII dogs after neonatal gene therapy}

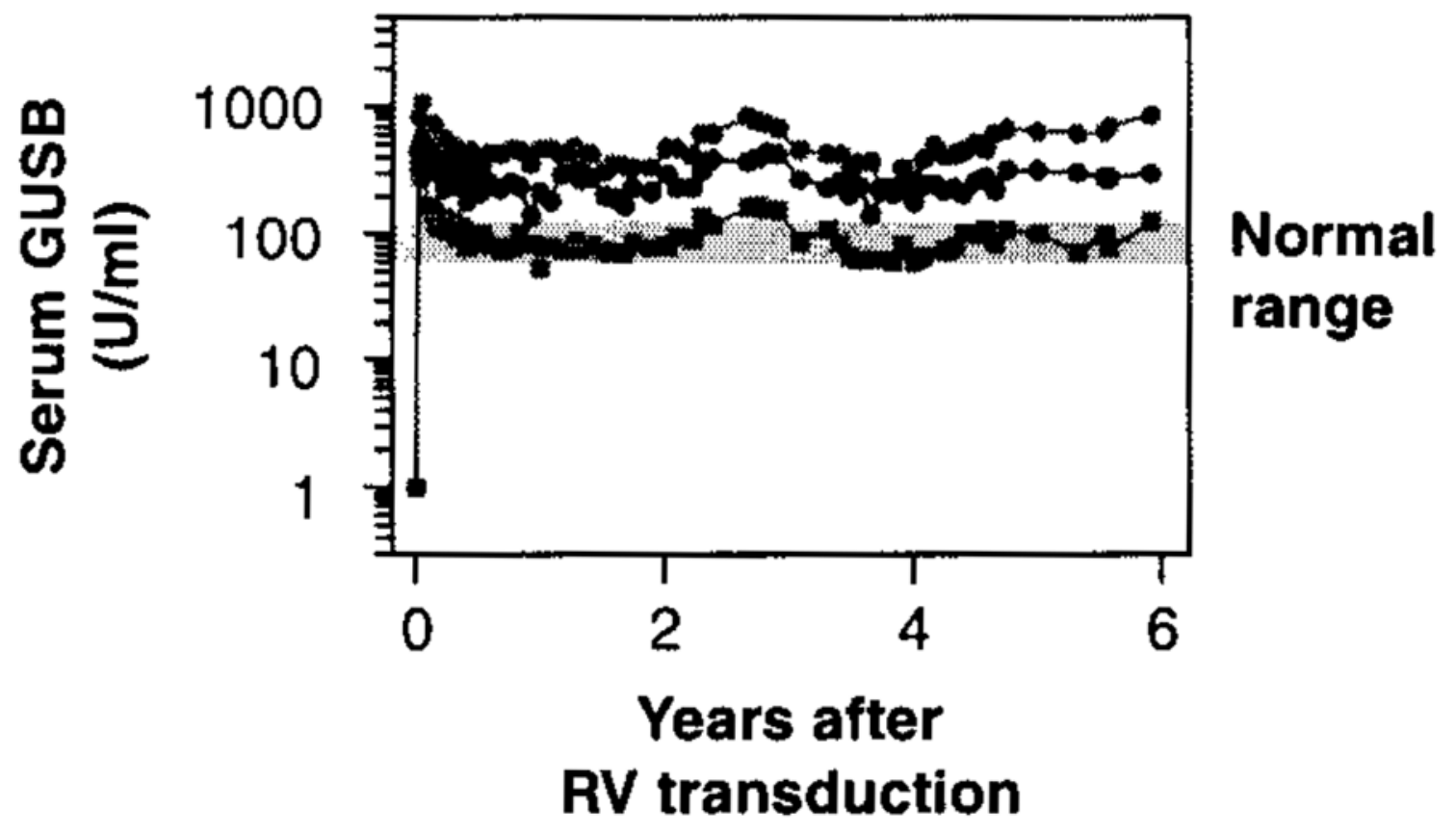

Figure 1. Long-term expression of GUSB in MPS VII dogs after neonatal retroviral vectormediated gene therapy

Newborn MPS VII dogs were injected i.v. with $3 \times 10^{9}$ transducing units/kg of a retroviral vector with the human $a_{1}$-antitrypsin promoter upstream of the canine GUSB cDNA [29], Serum GUSB activity is shown on a semilog plot versus the age years after retroviral vector transduction. The enzyme activity prior to gene therapy was $<1 \mathrm{U} / \mathrm{ml}$, as indicated by the initial data point. The serum activity in normal dogs Is indicated by the shaded region. GUSB: Serum $\beta$-glucuronidase; MPS: Mucopolysaccharidosis. 


\section{Table 1}

Summary of MPS syndromes.

\begin{tabular}{|c|c|c|c|}
\hline Disease & Enzyme & $\begin{array}{l}\text { GAG metabolized by the } \\
\text { deficient enzyme }\end{array}$ & Organs affected \\
\hline $\begin{array}{l}\text { MPS I } \\
\text { Hurler, Scheie }\end{array}$ & a-L-iduronidase & Dermatan and heparan sulfate & Brain, heart, bone, joints, eye, other \\
\hline $\begin{array}{l}\text { MPS II } \\
\text { Hunter }\end{array}$ & Iduronate sulfatase & Dermatan and heparan sulfate & Brain, heart, bone, joints, eye, other \\
\hline $\begin{array}{l}\text { MPS IIIA } \\
\text { Sanfilippo A }\end{array}$ & Heparan $N$-sulfatase (sulfaminidase) & Heparan sulfate & Brain \\
\hline $\begin{array}{l}\text { MPS IIIB } \\
\text { Sanfilippo B }\end{array}$ & a- $N$-acetyl-glucosaminidase & Heparan sulfate & Brain \\
\hline $\begin{array}{l}\text { MPS IIIC } \\
\text { Sanfilippo C }\end{array}$ & Acetyl-CoA:a-glucosaminide acetyltransferase & Heparan sulfate & Brain \\
\hline $\begin{array}{l}\text { MPS IIID } \\
\text { Sanfilippo D }\end{array}$ & $N$-acetylglucosamine 6-sulfatase & Heparan sulfate & Brain \\
\hline $\begin{array}{l}\text { MPS IVA } \\
\text { Morquio A }\end{array}$ & Galactose 6-sulfatase & $\begin{array}{l}\text { Keratan sulfate, chondroitin } \\
\text { sulfate }\end{array}$ & Bone, joints, eye, other \\
\hline $\begin{array}{l}\text { MPS IVB } \\
\text { Morquio B }\end{array}$ & $\beta$-Galactosidase & Keratan sulfate & Heart, bone, joints, eye, other \\
\hline $\begin{array}{l}\text { MPS VI } \\
\text { Maroteaux-Lamy }\end{array}$ & $\mathrm{N}$-acetyl-galactosamine 4-sulfatase & $\begin{array}{l}\text { Dermatan sulfate, chondroitin } \\
\text { sulfate }\end{array}$ & Heart, bone, joints, eye, other \\
\hline $\begin{array}{l}\text { MPS VII } \\
\text { Sly }\end{array}$ & $\beta$-Glucuronidase & $\begin{array}{l}\text { Dermatan, heparan and } \\
\text { chondroitin sulfate }\end{array}$ & Brain, heart, bone, joints, eye, other \\
\hline MPS IX & Hyaluronidase & Hyaluronan & Joints, bone \\
\hline
\end{tabular}

GAG: Glycosaminoglycan; MPS: Mucopolysaccharidosis. 
Table 2

Effect of intravenous injection of vectors in mouse models when organs other than just liver and spleen were evaluated for pathologic or functional correction of disease.

\begin{tabular}{|c|c|c|c|c|}
\hline Disease & Vector & Age & $\begin{array}{l}\text { Serum enzyme activity (fold } \\
\text { normal) }\end{array}$ & Effect \\
\hline \multirow[t]{5}{*}{ MPS I } & $\begin{array}{l}\text { AAV2 with CMV- } \beta \text {-actin } \\
\text { promoter [27] }\end{array}$ & Neonatal & $\begin{array}{l}\text { 5-fold normal at } 1 \text { month, } \\
\text { probably higher earlier }\end{array}$ & $\begin{array}{l}\text { Partially reduced disease in bone and } \\
\text { cerebellum; no vector in brain }\end{array}$ \\
\hline & \multirow[t]{2}{*}{$\begin{array}{l}\text { Lentiviral with MND } \\
\text { promoter [50] }\end{array}$} & Neonatal & Not tested & $\begin{array}{l}\text { Improved bone, survival, and brain; vector } \\
\text { copies in brain }\end{array}$ \\
\hline & & Adult & Not tested & Little improvement \\
\hline & $\begin{array}{l}\gamma \text {-Retroviral vector with } \\
\text { liver hAAT promoter } \\
{[22,23]}\end{array}$ & Neonatal & $\begin{array}{l}\text { High }=500 \text {-fold normal } \\
\text { Low }=15 \text {-fold normal }\end{array}$ & $\begin{array}{l}\text { Profound improvement in brain, heart, eye and } \\
\text { aorta with high serum activity; partial } \\
\text { improvement with low serum activity except in } \\
\text { aorta }\end{array}$ \\
\hline & $\begin{array}{l}\gamma \text {-Retroviral vector with } \\
\text { liver hAAT promoter }[28]\end{array}$ & Adult & 40-fold normal & $\begin{array}{l}\text { Partial improvement in brain, ear, and eye; little } \\
\text { improvement in aorta }\end{array}$ \\
\hline MPS II & $\begin{array}{l}\text { AAV2 with liver TBG } \\
\text { promoter [14] }\end{array}$ & Adult & 17-fold normal & $\begin{array}{l}\text { Reduced storage in brain, improved bones and } \\
\text { locomotion }\end{array}$ \\
\hline MPS IIIB & $\begin{array}{l}\text { Lentiviral with PGK } \\
\text { promoter [100] }\end{array}$ & Adult & Not reported & Some improvement in body weights \\
\hline \multirow[t]{6}{*}{ MPS VII } & \multirow[t]{2}{*}{$\begin{array}{l}\text { AAV2 with CMV- } \beta \text {-actin } \\
\text { promoter }\end{array}$} & Neonatal & $\begin{array}{l}1 \% \text { normal at } 2 \text { months; higher } \\
\text { earlier [25] }\end{array}$ & $\begin{array}{l}\text { Reduced storage in brain, heart valve; cornea not } \\
\text { corrected }\end{array}$ \\
\hline & & Neonatal & $\begin{array}{l}100 \% \text { normal at } 2 \text { months; higher } \\
\text { earlier [24] }\end{array}$ & $\begin{array}{l}\text { Partially improved growth, bones, hearing, } \\
\text { vision, and lifespan }\end{array}$ \\
\hline & $\begin{array}{l}\text { AAV2 with liver hAAT } \\
\text { promoter [26] }\end{array}$ & Neonatal & $\begin{array}{l}5 \% \text { normal at } 2 \text { months; higher } \\
\text { earlier }\end{array}$ & $\begin{array}{l}\text { Modest reduction in brain storage, partial } \\
\text { improvement in hearing, vision and bones; } \\
\text { survival not improved }\end{array}$ \\
\hline & $\begin{array}{l}\text { AAV2 with CMV promoter } \\
{[101]}\end{array}$ & Neonatal & $\begin{array}{l}100 \% \text { normal at } 2 \text { months; } \\
\text { probably higher earlier }\end{array}$ & Improved bone and reproduction \\
\hline & $\begin{array}{l}\text { Gamma retroviral with liver } \\
\text { hAAT promoter [21] }\end{array}$ & Neonatal & $\begin{array}{l}\text { High }>150 \text {-fold normal; medium } \\
50 \text { - to } 150 \text {-fold normal; low } 15- \\
\text { to } 50 \text {-fold normal }\end{array}$ & $\begin{array}{l}\text { Markedly improved bone, brain, eye, and aorta } \\
\text { with high expression; partial improvement with } \\
\text { medium or low expression }\end{array}$ \\
\hline & $\begin{array}{l}\text { Adenoviral with CMV- } \beta \text { - } \\
\text { actin promoter }[102,103]\end{array}$ & Neonatal & Not reported & Improved bone, eye, brain \\
\hline
\end{tabular}

AAV: Adeno-associated virus; CMV: Cytomegalovirus; hAAT: Human a 1-antitrypsin; MPS: Mucopolysaccharidosis; PGK: Phosphoglycerol kinase. 


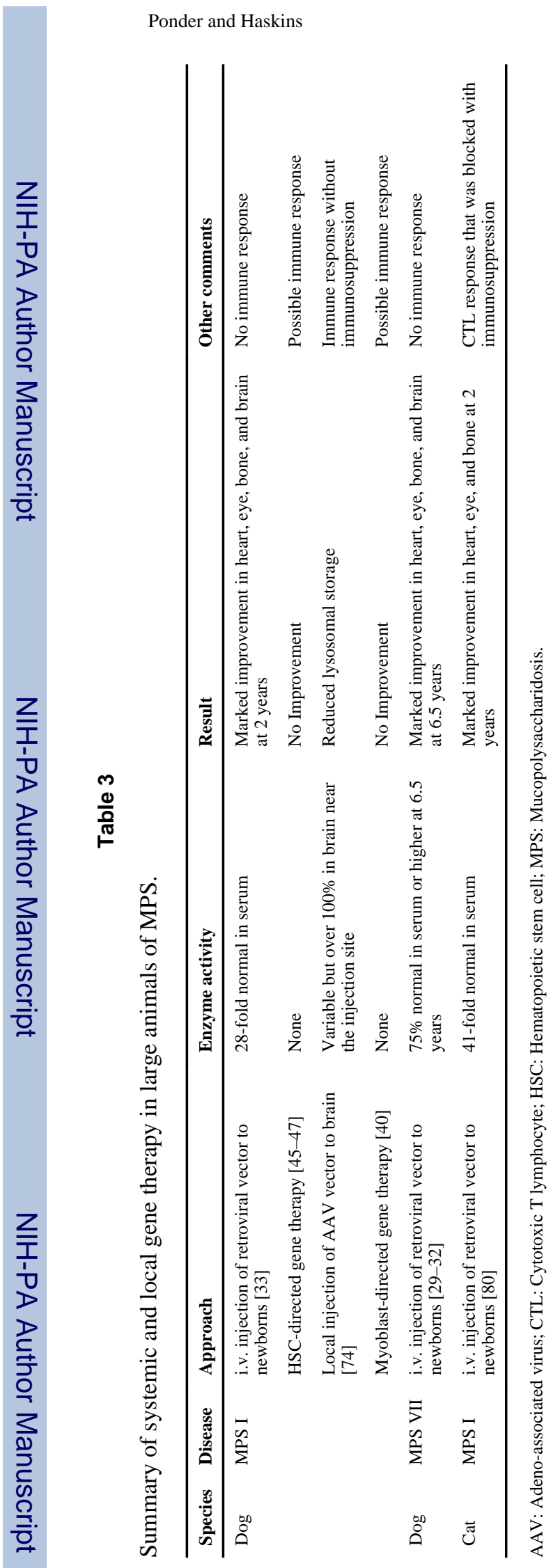

Page 20 


\section{Table 4}

Effect of localized gene therapy to brain on neurologic function in mice.

\begin{tabular}{|c|c|c|c|}
\hline Disease & Vector & Injection route & Effect \\
\hline MPS IIIB & AAV 5 better than AAV2; PGK promoter [56] & Striatum of adults & $\begin{array}{l}\text { Improved neurologic function and } \\
\text { behavior, reduced storage }\end{array}$ \\
\hline \multirow[t]{6}{*}{ MPS VII } & AAV5 with RSV promoter [58] & Striatum of adults & $\begin{array}{l}\text { Improved neurologic function, reduced } \\
\text { storage }\end{array}$ \\
\hline & AAV4 with RSV promoter [63] & Lateral ventricle of adults & $\begin{array}{l}\text { Improved neurologic function, reduced } \\
\text { storage }\end{array}$ \\
\hline & $\begin{array}{l}\text { EX vivo transduction of bone marrow stromal } \\
\text { cells with retroviral vector with MND promoter } \\
{[67]}\end{array}$ & Lateral ventricle of newborns & $\begin{array}{l}\text { Improved neurologic function and } \\
\text { reduced storage despite decline in } \\
\text { expression after } 2 \text { months }\end{array}$ \\
\hline & AAV1 with GUSB promoter [64] & $\begin{array}{l}\text { Lateral ventricle at } 15 \text { days } \\
\text { gestation }\end{array}$ & Improved survival, reduced storage \\
\hline & AAV2 with CMV- $\beta$-actin promoter [71] & $\begin{array}{l}\text { Anterior cortex and hippocampus of } \\
\text { newborns }\end{array}$ & $\begin{array}{l}\text { Improved neurologic function, reduced } \\
\text { storage }\end{array}$ \\
\hline & Lentiviral with RSV promoter [60] & Striatum of adults at 4 months & $\begin{array}{l}\text { Recovery from established neurologic } \\
\text { deficits }\end{array}$ \\
\hline
\end{tabular}

This table only reports studies in which evaluation of neurologic function was performed. Studies that report the effect on enzyme activity and/or lysosomal storage in the brain are discussed in the text.

AAV: Adeno-associated virus; CMV: Cytomegalovirus; GUSB: Serum $\beta$-glucuronidase; MPS: Mucopolysaccharidosis; PGK: Phosphoglycerate kinase. RSV: Rous sarcoma virus. 